\title{
An Introduction to Hip-Hop Culture in Guinea-Bissau: The Guinean Raperu
}

\author{
FEDERICA LUPATI
}

CHAM, Universidade Nova de Lisboa

\begin{abstract}
This article discusses the provenance and emergence of hip-hop culture as a form of resistance in Guinea-Bissau. It describes a political backdrop of national instability and how contemporary Guinean hip-hop forms took their cue from 1970s New York. It discusses the political stances of Guinea's most celebrated hip hop artists.
\end{abstract}

Keywords: Popular music, Rap, Politics, Nation, Contemporary Africa

Hip-hop culture emerged in the 1970s in New York's black neighborhoods, particularly in the Bronx. With roots in Kingston, Jamaica, it found a rich space for its development in block parties, during which neighbors gathered in the streets or houses with a DJ playing samples to keep the party going.

In other words, hip-hop did not start as a political movement but as an aesthetic manifestation. It had no manifesto and no statement of belief. It was a way for neighbors to pass the time together, enjoy music, and have fun. Subsequent generations, however, felt the weight of a politics of abandonment and oppression. This gave their musical entertainment a different meaning. As Jeff Chang argues, hip-hop came to represent a moment of free expression and self-manifestation, where the rough rules of daily life were suspended in order to make space for peaceful interaction through music and dance.

Against a backdrop of increasingly violent gang wars, illicit activities, and 
heavy-handed police repression, the new generation found a different way to express itself through deejaying, emceeing, breakdancing, and graffiti art. These were forms of political action, and they laid the groundwork for what became a much wider, deeply conscious, and globally dispersed cultural movement.

Hip-hop culture provided a young, urban generation with new and powerful symbolic tools to combat its marginalization and subalternity. It was as if these young people had answered Gayatri Spivak's concerns, proclaiming through their cultural practice, "Yes, we can speak."

Hip-hop culture represents the starting point for the development of new local identities, foregrounding the right to self-determination, self-awareness, and the voice of those who hitherto were easily ignored and left in the shadows. From its inception, rappers fused in their rhymes and rhythms elements from an African heritage and Afro-descendants' history with stories from daily life in the streets of big cities. They thus increased awareness and conveyed the living conditions of the marginalized, as well as staking a claim to public action. They talked to and for their people.

At a social level, the role of rappers was that of spokespersons for the community, acting as legitimized witnesses and narrators who made the community's reality known to others beyond where they lived. This function reminds us of the historically important presence of griots in West African societies and the traditional values and beliefs they carried through their stories, essential in the building of different socio-cultural identities.

Richard Shusterman points out that rap music (the verbal component of hiphop culture) has ancient origins. The art of poetry, which is central to rap's style and self-understanding, has always celebrated its ability to incorporate traditional wisdom, ideals, and deep religious beliefs embodied in the myths and experiences of ancient cultures. He suggests that the dichotomy between poetry and philosophy has traditionally led to the conclusion that "art is somehow only fiction and deceit rather than a powerful reality that can purvey the truth and represent in ways just as powerful as scientific and philosophical discourse," and that "art pertains only to a pure aesthetical sphere, entirely apart from the real world of practical and political action" (55-56).

For Shusterman, one of the most interesting and revolutionary aspects of hiphop culture is the challenging of this dualism. As he argues: "some of the most thoughtful MCs [i.e., rappers] claim not only to be creative artists but also 
philosophers; and they see their artistic expression of truth as part and parcel of a political struggle to achieve greater economic, social, political and cultural power" (55). The subversion of traditional theoretical divisions is part of what he calls the deep "philosophy of the mix," which finds its expression also in the aesthetic techniques of sampling.

As a cultural manifestation, hip-hop can also be linked to African origins through diaspora, and to the space Paul Gilroy theorized as the Black Atlantic. Gilroy looks at black music in general, and hip-hop music more specifically, as an example of musical, social, and political fusion. Observing the North American phenomenon, he argues:

... the musical components of hip hop are a hybrid form nurtured by the social relations of the South Bronx, where Jamaican sound system culture was transplanted during the 1970s and put down new roots. In conjunction with specific technological innovations, this routed and rerooted Caribbean culture set in train a process that was to transform black America's sense of itself and a large portion of the popular music industry as well. (33)

African cultures in the diaspora have never avoided contact with other cultures and have never formed a homogeneous group. In some ways, the African diaspora represents a nation without territory and without a state, therefore putting its constituents in constant need of cultural and historical affirmation while giving rise to a continuous process of hybridization.

Its aesthetics accentuate the hybridity and fragmentation of the black subject, now even more in conflict because of questions of class and gender. As part of the productions of black music, hip-hop opposes the world as it is, confronting it with a world that the marginalized would like to see. Gilroy notes two functions of hip-hop music: the first is "fulfillment," which demands that modernity delivers what it promised, while the second is "utopian," through which music presents alternatives to the modern vision of society (36). Through its symbolic expression, hip-hop culture points to the existence of a transnational, political, and cultural sphere that incorporates and inspires local expressions, and is characterized by very different and unique national manifestations.

Hip-hop aims at negotiating between the experiences of marginalization, 
oppression, and ethnic prejudice, through the constant exercise of meta-language that allows it to translate the feeling of injustice lived at the margins of society. For this reason, as Rosana Martins asserts:

O hip-hop é uma arte reconhecida como ferramenta educativa e tem potencializado seu caráter político e transformador, de autorreflexão, canais de participação e de pertencimento histórico (ligação com o passado) e social (ligação com o presente) capaz de viabilizar espaços de aprendizagem, conhecimento e de ampliação da cidadania. (46)

She goes on to claim that the identitary narrative in hip-hop culture "se constrói por meio de uma reflexividade que tem um papel muito importante no processo de (re)construção, e (re)significação das subjetividades dos atores sociais, o sujeito que reflete sobre seu social e se torna o protagonista social de sua própria história" (46).

Pulling together these core concepts, hip-hop culture can be considered to have very remote origins because of its poetic and spoken elements, which, combined with music, remind us of the ancient transmission of myths and founding values. It also manages to overcome the traditional dichotomy between art and philosophy or poetry and politics because, through its expressions, a true acknowledgment of reality can take place. It defines new identities, connecting spatially, historically, and culturally different areas. It spreads a new idea of negritude and is intrinsically connected to Gilroy's Black Atlantic. Finally, hiphop represents a narrative of identity, playing a crucial role in the building of new, conscious subjects and protagonists of life:

A existência das subculturas juvenis ligadas ao hip-hop acabam por dar margem a novas leituras, em formatos que levam a repensar o espaço e estrutura societária. Assim, tomando como exemplo a difusão do rap, através dos meios massivos, enquanto fluxo cultural que se circula globalmente, podemos verificar que o mesmo encontra-se ancorado na ideia de cultura (hip-hop culture) que permite a imaginação de uma comunidade mundial (hip-hop nation), fundada no protesto contra a injustiça e a opressão social. (Martins 229) 
Globalization and mass media have played a crucial role in spreading the seeds of hip-hop culture around the world. By making its way through time and space, hip-hop has morphed into a wider phenomenon, reaching more young people of various racial and ethnic origins. Hip-hop music is no longer exclusively a creative strategy specific to Afro-descendants. It has become a channel for the expression of the life experience of people from different areas, who often share a socio-political context. Once established in the USA, hip-hop spread around the globe and has made its way back to Africa.

\section{Hip-hop in Guinea-Bissau}

The image of symbolic travel is relevant when studying hip-hop culture in Guinea-Bissau, because it points to a phenomenon of cultural re-appropriation and of indigenization. Hip-hop culture has had a strong impact in Guinea-Bissau since its first appearance in the 1990s. With wide circulation in the broader African context, rap has grown quickly in the recent past.

Having at first great significance for the diaspora, it is no longer tied to an expatriated territoriality. Guinean rap, in fact, is one of the most powerful tools used by local groups to fight political and social battles, and it is strongly rooted in local history and culture. Despite first being an aesthetic movement, it soon became a political one, responsible for presenting an authentic voice of sociopolitical opposition and articulating demands for civil rights and justice.

Since gaining independence in 1973, Guinea-Bissau has struggled to build democratic institutions and establish a stable state. Its recent political history has seen deep social transformations. There have been political discontinuities, and the state's perpetual instability has resulted in the creation of precarious political institutions that have not served the needs of the country well. The justice system has a history of weakness and a ruling class has fought for power against an oftignored backdrop of poverty. The principles of inclusion and equality-which lay at the center of the independence movement-have often been forgotten.

In Guinea-Bissau, the military has exercised substantial power, interfering often with civilian leadership by making and unmaking alliances on the basis of interests often connected to drug trafficking. In the nine years from 1994 (when the first multi-party elections took place) to 2012, the country has suffered four military uprisings. Three of these were full-blown coups d'état. 
When President João Bernardo "Nino" Vieira dismissed his military chief of staff, Ansumane Mané, for alleged involvement in the arms trade, he ended a delicate stability reached in the previous years of government. The first coup, led by Ansumane Mané, took place in 1998 and led to a civil war (known as the Guerra de 7 de Junho), during which President Vieira was deposed and a military junta took over. Eleven months later, new elections were held, and Kumba Yalá emerged as the new head of state.

The new president took office in 2000 but was removed in 2003 by a second coup. Henrique Rosa provisionally took his place, and after another attempted military uprising in 2004, Nino Vieira was re-elected in 2005, six years after being ousted from office. A group of soldiers killed him in May 2009, and Malam Bacai Sanhá became president as a result of the elections held a month later. Due to a prolonged illness, President Sanhá frequently left the country for medical treatment. During one of his stays abroad, in April 2012, Major General Mamadu Ture Kuruma led a coup that took over the capital and replaced the interim president, Raimundo Pereira, with Manuel Serifo Nhamadjo. Following contested elections in 2014, José Mário Vaz became the nation's president.

Guinea-Bissau's political unrest, as well as the state's inability to control large tracts of the nation's territory and redress high levels of poverty, eventually attracted the attention of international drug traffickers. With the growth in the consumption of cocaine in Europe and Russia in the late 1980s and early 1990s, Guinea-Bissau became the center of illicit trade connecting South America and Europe. As Miguel de Barros, Patrícia Godinho Gomes, and Domingo Correia point out, the lack of control of the territory and the high levels of corruption and poverty were decisive factors that facilitated the establishment of strong connections with transnational crime networks, rendering Guinea-Bissau one of the most important nodes for drug trafficking in the world (146). The presence of drug traffickers was certainly not the cause of the country's instability, but it has accentuated and profited from internal political and social conflicts.

As a reaction to Guinea-Bissau's political situation and its repercussions in the social sphere, new ways of building resistance and protest against injustice and inequality emerged in a cultural space where music has historically represented a forceful channel for intervention and hope (Borszink 339). Transmitted across urban and rural environments by radio, rap made its appearance in Guinea-Bissau in the 1990s and soon became the means by which 
people claimed their rights and severely criticized government corruption and incompetence. As the Guinean raperu (rapper) As One explains:

Havia também hip hop americano que passava já na rádio da GuinéBissau ... mas nunca se tinha tido coragem de cantar hip hop porque naquele tempo as pessoas que cantavam na rádio eram associadas a banditismo. Muitas pessoas que queriam cantar hip hop escondiam-se. É em meados de 90s que uma das primeiras músicas de hip hop sai. É uma música que canta o governo. Que o critica duro. A música chama-se Colisensa: 'Coli colissença, bo pistanu no bandera, Coli colissença, bo danu no terra.' Esta é uma das primeiras músicas. É de Naka-B.

Guinean rappers sang and continue to sing in Creole, a lingua franca spoken by almost $60 \%$ of the population and used as a tool meant to transcend differences and allow people to recognize the message of continued struggle. As AnneKristin Borszik points out, "during the independence struggle, composing in Kriol was intended to convey political messages beyond Portuguese reach, [however] artists nowadays have recourse to this language to promote national identity and unity" (334).

Since its beginning, Guinean hip-hop spoke of what was rooted in the land, and the use of Creole represents the conscious search for cultural authenticity. Rap in Guinea-Bissau is not simply a product of influences coming from abroad. It is the result of the recreation of the nation's contemporary situation and rests on the invention of new paradigms that translate the specificity of a particular time and space. Permeated with an adapted and imported originality of form, it is deeply linked to local tradition and history.

By building their own personal narratives imbedded in Guinea-Bissau's everyday life, the raperus quickly became spokespersons for their people, singing their stories and their realities. Many people could easily identify with the experiences the raperus related, and they felt their own presence acknowledged and their voices legitimized. Encouraged by positive feedback from the public, Guinean rappers began to proliferate in the late 1990s. Real GX, BMJ, Mário G, Cientistas Realistas, and Masta Tito are among the pioneering names of Guinean hip-hop, and they are generally referred to as the New Generation. They laid the foundations of the movement and showed how 
traditions could be reinvented and transformed into new forms of expression and affirmation.

As a social product, Guinean hip-hop was born from the need of younger generations, growing up in a globalized context and witnessing the disintegration of the nation's youth organizations, to reinvent forms of sociability (Lima 388). Hip-hop culture and the values it transmitted appeared to be the best way to take ownership of freedom of expression, essential for democracy. It became a marker of the right to protest against increasingly violent and corrupt political conditions. Indeed, as a political product, it arose as the instrument of an excluded youth (Andrade 86), uneasy with the lack of democracy and the inability of the governing class to solve the challenges facing the nation.

Rap gradually changed the sociocultural identity of Guinea's young generations, particularly in urban areas. It transformed them into active, dynamic agents within society, providing them with non-canonical tools to assert their presence. Through their music, they promoted change.

The process of canonization within a cultural system mirrors the universal struggles for power characteristic of every human society. According to Itamar Even-Zohar, every cultural system needs a balance between its stratified layers, in order to regulate the system, keep its hierarchies in check, and ensure that the system does not collapse. The system's balance comes from the opposition between its different strata. Without an input from a strong subculture, every socio-cultural system will stagnate and metaphorically die (26).

Adapting Even-Zohar's observations to Guinea-Bissau's cultural landscape helps us to understand the historical importance of the centrifugal forces of the nation's subculture. Their use of music has long been one of the strongest strategies to express protest and non-conformist thought, a strategy replicated in much of Africa. In Guinea-Bissau, hip-hop rose as a full-fledged counterculture.

The specificities of Guinean hip-hop are connected to the nation's traditions, history, and especially politics. Hip-hop has played a crucial role during electoral campaigns, for example, by scrutinizing parties and reporting brutal events in a lyrical form. Masta Tito, one of the most popular raperus in Guinea-Bissau, is paradigmatic of the interface between hip-hop and a politics of resistance (Rocha). A committed activist, his songs often make specific references to contemporary political struggles, taking very clear, progressive, and democratic positions. In his 2013 release, "No kansa golpe" 'Endless coup,' for example, he 
sings about the coup d'état of April 2012 in a very direct way:

Kulpasinhu kulpa garandi tudu i kulpa / golpesinhu ku golpe garandi tudu i golpe / kondena tudu i kondena / ... Serifo Nhamadjo i presidenti pabia PRS fasi golpe.

[A little blame, a lot of blame, everything is blame / a little coup, a big coup, everything is coup / condemnation, everything is condemnation / ... Serifo Nhamadjo is president because the PRS staged a coup.]

Masta Tito is one of many raperus who infuse their work with politics and poetic rawness. Other artists, such as Cientistas Realistas, As One, F. B. M. J., Bunca MC, Rock Salim, Dama Cotche (Os Bravos), Raça Preto, Fil Cap, Best Friends, Daw Tchaw, Baloberos, and Torres Gémeos attack public figures and position themselves against corruption, the drug trade, and injustice (Lima and Barros).

As Miguel de Barros, Patrícia Godinho Gomes, and Domingo Correia explain, there are different types of narratives within Guinean rap, though all share political aims. Baloberos, for example, focuses on the fight against the drug trade in their track "Bo obi mas" 'Listen again':

Guiné-Bissau nason di trafico? Tráfico! / kil ku na bin bai pa Spanha? Tráfico! / kil ku ta bin di Colombia? Tráfico! / Mira, hermanos- la fuerza armada transportando la cocaína en cantidad / haciendo negocios con nuestros hermanos de Colombia / Bo obi es sistema di pesa coca: kilograma, decagrama, hectograma, grama.

[Guinea Bissau is a country of drug traffic? Traffic! / What goes to Spain? Traffic! / What comes from Colombia? Traffic! / Look, brothers - you can see the military transporting big quantities of cocaine / doing business with our brothers from Colombia / Listen to the weighing system of cocaine: kilograms, decagrams, hectograms, grams.]

A different narrative is found in the music of Cientistas Realistas, who sing of restlessness. As One's lyrics can be considered narratives of action, while F. B. M. J. focuses on protest. Finally, Torres Gémeos's work can be read as narratives of accusation (Barros, Gomes, and Correia. 152-53). 
Masta Tito is perhaps the most emblematic figure of Guinean hip-hop. He enjoys the status of régulo-a term used during the Portuguese colonial era to designate imposed native leadership structures, now applied to the wise and charismatic. As Barros reminds us, in an interview with Rádio Voz da América, Masta Tito declared himself a "spokesperson of the Guinean people," stating that he only "sings the truth" (193).

Before rapping against the 2012 coup, Masta Tito had been a vocal supporter of Manuel Serifo Nhamadjo, who promised a future of peace, justice, and harmonious growth for the country. Masta Tito went so far as to produce a track in which he invited the people to vote for Nhamadjo, and he made frequent appearances at the candidate's election rallies.

Nhamadjo, once affiliated with the PAIGC (the party founded by Amílcar Cabral) and a member of the national assembly, ran in 2012 as an independent because his party had given its support to Carlos Gomes Júnior. Nhamadjo came in third in the first round of the elections of March 2012. Following that year's coup, the military chose him as the country's transitional president.

During the campaign, Masta Tito produced the track "Anos i di Nhamadjo" 'We belong to Nhamadjo,' which contains the lines:

Anos i di Nhamadjo / viva Nhamadjo / omi balenti / anós tudu no kontenti manera ku sta presenti / omi di paz / omi capaz / Nhamadjo i AS / omi santu / ... Nhamadjo ka usus / omi limpu pus / suma si pensamento / pa Guiné mela tchut / ... povo kudji paz / Nhamadjo bin ku paz / Nhamadjo i capaz / povu misti paz / povu di Guiné no vota na Nhamadjo.

[We belong to Nhamadjo / Long live Nhamadjo / A brave man / We're all happy that he's here / A man of peace / a capable man / Nhamadjo is an ace / a saintly man / ... Nhamadjo is not dirty / He's even too clean / like his thought / that Guinea will be just honey / ... The people have chosen peace / Nhamadjo brought peace / Nhamadjo is capable / The people want peace / People of Guinea, let's vote Nhamadjo.]

After making this clear statement of political support, Masta Tito became the beneficiary of military patronage, in particular that of the chief of the Defense 
Forces, and he was even invited to perform at their meetings (Barros 194). This put the famous raperu at odds with many in the hip-hop community, who felt he was betraying his role of régulo and working in favor of the people he had been fighting up until then. Others praised his stance, seeing it as a willingness to take action and advocate for change in the country. This collaboration must also be understood in light of the fact that rappers have often been persecuted by Guinea's military, who would shut down their shows or prevent them from meeting. As Borszik states: "music censorship is a highly politicized phenomenon, and hip-hop groups like F. B. M. J. and Baloberos, who overtly criticize politicians, have become the target of censorship" (334).

MCs often criticize corruption and accuse "incompetent politicians" of being unable to rule the country and causing the population's suffering. In "Kaminhu sukuru” 'Dark road,' F. B. M. J. addresses Guinea-Bissau's rulers directly, talking to President Nino Vieira and accusing him of stupidity:

Guiné i ka terra ku pobre pa natureza / Ma sim se governantis ku burru pa natureza / Furta povo, udju ku udu / Kumpra casa na estrangeiro / Kumpu terra di djintis / dixa mama Guine mandinti / Presilino Presilino kudzu

[Guinea isn't a poor land by nature / But its politicians are stupid by nature / They steal from the people, eye to eye / They buy houses abroad / They build in other people's lands / They abandon the sick mother Guiné / Presilino, Presilino listen to us.]

N'pans is another example of a critical rapper, albeit less harsh and subtler in his critique. He now lives in Russia, where he has attained a degree of notoriety. His music continues to be rooted in Guinea's traditions. In "Conversa di bardadi" 'True conversation,' he uses musical references familiar to Guineans, quoting a phrase from a famous song by José Carlos Schwarz, "Si bu sta dianti na luta" 'When you're standing on the front line,' and using the classical melody of Super Mama Djombo's "Julia" (Borszik 337). His goal is to appeal to the president's sense of responsibility in building up the nation. He calls on him to be a "good father" and to create peace and progress: 
Bardadi situaçon sta gravi / Campo kinti / Amílcal Cabral / heroi ma garandi / Aonti bu matado / aos bu fidjus na sufre cansera garandi.... / Camarada president / Nha voz sai di lundju pa i bim pertu bo / Lantandano no Guiné pa i sedo ma bonito na e mundo / Tem paciencia pega bu povo / Pa i ka sinti falta di nada / Aos abo ki pape di terra / Abo ki no guarda / No ka misti pa guerra ripiti mas.

[It's true, the situation is serious / The field is hot / Amílcar Cabral / the greatest hero, / yesterday they killed you / Today your sons are very tired.... / Comrade President / my voice came from far away to get close to you / Make our Guinea rise / in order for her to be the most beautiful in the world / Be patient, hold your people / so they don't miss anything / Today you are the father of the land / You are our guardian.]

Guinean hip-hop draws connections with history and historical figures, making use of national heroes to legitimatize their struggles. Important in this regard is Amílcar Cabral, who is a central symbolic element in many rappers' lyrics, such as Torres Gemeos' "Culpadus" 'Blamed,' N'Pans' "Fidjus di Guiné" 'Children of Guinea,' and Cientistas Realistas's “Contra," among others.

Cabral is often an example of a good guide who gave hope to the people, in opposition to the corrupted and ideologically barren figures currently in power. In "Guiné ka na fika sin" 'Guinea can't go on like this,' F. B. M. J. sing:

Amílcar Cabral / Omi ku ta pensaba futuru di no tera ... Bu nomi ku n ta ronka / I bu bandera na nha testa / Bu inu na nha boka ... / nha identidadi nunka $n$ ka na disisti de

[Amílcar Cabral / when I think about the future of our land / your name appears / and your flag on my forehead / your hymn in my mouth / my identity, I'll never give it up.]

In this way, Guinean raperus present Cabral as an important part of their identity and a source of pride (Barros and Lima 105-06).

Cabral is also often compared to "the MC," the rapper as the harbinger of truth, who fights for the people. This approximation allows rappers to consider themselves as legitimate successors of his struggle and his political thought, and 
some artists seek true legitimization by using Cabral's voice and even inserting his speeches into their tracks: Sindykatto de Guetto and Rhyman are examples of artists who have made use of this technique.

The appropriation of a historically central figure by the raperus indicates their desire for legitimation and cultural redemption, as well as their desire for a resolution to decades of political struggle. At the same time, it shows their understanding of the historical path of their country and a sense that they can reinvent tradition. Once again, the raperu transmits fundamental cultural values that define the identity of the people.

In Guinea-Bissau, the raperu's interventional character, expressed through daring messages and direct interest in politics and social issues, have given rap a wider visibility and more influence than ever, establishing it as a robust counterculture. It represents today an instrument by which young Guineans take action and work to make an impact on the world around them. It has given a voice to people largely left behind by political and economic elites, granting them the opportunity to become active citizens and conscious narrators of their realidade. Beyond this, Guinean hip-hop also constitutes a rich example of the role of hiphop culture in a post-colonial society.

\section{Works Cited}

Andrade, Elaine Nunes de. "Hip-hop: movimento negro juvenil." Rap $e$ Educação/Rap é Educação. Ed. Elaine Nunes de Andrade. São Paulo: Summus, 1999. 83-91. Print.

Baloberos. "Bo obi mas." YouTube. 3 Jul. 2011. Web. 26 May. 2016.

Barros, Miguel de. "Participação política juvenil através da música rap: dinâmicas de mobilização e protesto em contextos de 'suspensão' democrática na Guiné-Bissau.” Tomo 21 (2012): 169-200. Print.

—, Patrícia Godinho Gomes, and Domingos Correia. "Les conséquences du narcotrafic sur un état fragile: le cas de la Guinée-Bissau." Alternatives Sud 20 (2013): 145-58. Print

-, and Redy Wilson Lima. "Rap Kriol(u): o pan-africanismo de Cabral na música de intervenção juvenil na Guiné-Bissau e em Cabo-Verde.” Realis 2.2 (2012): 89-117. Print.

Borszik, Anne-Kristin. "Telling the Truth and Commenting Reality: 'Harsh 
Criticism' in Guinea-Bissau's Intervention Music." The Routledge History of Social Protest in Popular Music. Ed. Jonathan Friedman. New York: Routledge, 2013. 331-45. Print.

Chang, Jeff. Can't Stop Won't Stop: A History of the Hip-Hop Generation. New York: St. Martin's, 2005. Print.

Even-Zohar, Itamar. Polysystem Studies. Durham: Duke UP, 1990. Print.

F. B. M. J. “Caminho Sukuro.” YouTube. 11 Jan. 2009. Web. 26 May. 2016.

Gilroy, Paul. The Black Atlantic: Modernity and Double Consciousness. New York: Verso, 1993. Print.

Lima, Redy Wilson. "Rap Kriol(o): The Pan-Africanism of Cabral in the Music of Youth." Claim No Easy Victories: The Legacy of Amílcar Cabral. Ed. Firoze Manji and Bill Fletcher Jr. Dakar: CODESRIA/Daraja, 2012.387-404. Print.

Martins, Rosana. "Identidades transaltânticas da cultura hip-hop: estudos de caso no Brasil e em Portugal.” Opus 19.2 (2013): 223-42. Print.

- . "Construções de alteridade: políticas de pertença e cultura hip-hop." Periferia, 2.1 (2012): 41-57. Print.

Masta Tito. “Anos i di Nhamadjo.” YouTube. 1 Mar. 2013. Web. 26 May. 2016.

—, featuring Menina Ludi. "No kansa golpe.” YouTube. 27 Feb. 2013. Web. 26 May. 2016.

N'pans. "Conversa di Bardadi.” YouTube. 12 Oct. 2008. Web. 26 May. 2016.

Rocha, João Manuel. "Tudu ora son golpe é o rap como instrumento de resistência." O Público. 13 Apr. 2014. Web. 26 May. 2016.

Shusterman, Richard. "Rap Aesthetics: Violence and the Art of Keeping it Real." Hip Hop and Philosophy: Rhythm 2 Reason. Ed. Derrik Darby and Tommy Shelbie. Peru, IL: Carus, 2005. 54-64. Print.

Spivak, Gayatri Chakravorty. "Can the Subaltern Speak?" Marxism and the Interpretation of Culture. Ed. Cary Nelson. London: Macmillan, 1988. 271313. Print. 